\title{
Effects of Fe and Mn on Microstructure and Microhardness of Titanium Alloys
}

\author{
VICTOR GEANTA ${ }^{1}$, IONELIA VOICULESCU ${ }^{2}$, STEFAN TUDORAN ${ }^{3}$ \\ ${ }^{1}$ University Politehnica of Bucharest, Faculty of Materials Science and Engineering, Department of Engineering and \\ Management of Metallic Materials Obtaining, 313 Splaiul Independentei, 060042, Bucharest, Romania \\ ${ }^{2}$ University Politehnica of Bucharest, Faculty of Industrial Engineering and Robotics, Department of Quality Engineering \\ and Industrial Technologies, 313 Splaiul Independentei, 060042, Bucharest,Romania \\ ${ }^{3}$ Carol Davila University of Medicine and Pharmacy, 8 Eroii Sanitari Blvd., 050474 Bucharest, Romania
}

Abstract Titanium is one of the most appreciated biocompatible materials, as it possesses both good mechanical characteristics but also high corrosion resistance in contact with biological environments. Initially, Ti-6Al-4V trade mark was used for the manufacture of implantable medical devices, being usually selected for making aerospace structures. Over time, it has been found that aluminum and vanadium are not elements with acceptable biocompatibility, metallic ions being found either dissolved or accumulated in certain areas adjacent to the implants. Therefore, the development of titanium alloys dedicated to biomedical applications is still highly required. The effects of chemical elements (Al, Fe and $\mathrm{Mn}$ ) on the microstructure and microhardness of titanium alloys for medical applications are analyzed in the paper. The experimental alloys were obtained by melting of raw materials in an argon inert atmosphere of the VAR equipment, using high purity metallic elements. Has been developed Ti-base alloys that contain different concentration of 11 to $18 \mathrm{wt}$. \% Al, 2 to $7 \mathrm{wt}$. $\% \mathrm{Fe}$ and $6 \mathrm{wt} . \% \mathrm{Mn}$ for highlighting the effects of these elements on the micro-structure and microhardness of titanium alloys. SEM and EDAX analysis revealed the microstructure and microhardness changes occurred by using of alpha stabilizing elements (Al) or beta stabilizers (Fe, $\mathrm{Mn})$.

Keywords:titanium alloys, chemical composition, microstructure, microhardness

\section{Introduction}

The main advantage of titanium alloys are the elastic modulus value very close to that corresponding to the cortical bones. Also, low density and corrosion resistance into biological fluids chemical are salient features for implants. The biocompatibility of titanium and its alloys seems to be due to its capacity to slowly form of hydrated titanium oxide on the surface level, that allow the adherence of calcium and phosphorus to the broken zones of bones [1,2]. Alloying elements like Al and $\mathrm{V}$ in Ti6Al4V alloy seems to affect the biocompatibility due to dissolving as metallic ions, causing local accumulation or undesired adverse tissue reactions. [1,3,4].

The good workability and high mechanical strength are useful and desired characteristics that allow first choosing titanium alloys comparatively other metallic alloys. The keeping of low value for Young's modulus, similar to the cortical bones, is an important concern of scientist. The technological solutions applied until now for titanium alloys are cold working and heat treatments that can be effective to improving with around $20 \%$ of initial mechanical characteristics [1]. Another issue is assuring to the oseointegration of the implant, by good chemical biocompatibility and a low Young's modulus value [5-7].

Usually, titanium alloys can be classified into 3 main groups, depending on the microstructure, respectively Alpha, Alpha + Beta, or Beta alloys. Obtaining a certain type of structure is possible by choosing the chemical composition, which must contain elements that stabilize certain types of microstructural phases. In the case of titanium alloys, the elements that stabilize the Alpha phase are $\mathrm{Al}, \mathrm{O}, \mathrm{N}$ and $\mathrm{C}$, and those that stabilize the Beta phase are $\mathrm{Fe}, \mathrm{Mn}, \mathrm{Cr}, \mathrm{Cu}, \mathrm{Ni}$ and $\mathrm{Si}$ ). Other elements,

\footnotetext{
*email:ioneliav@yahoo.co.uk
} 
like $\mathrm{V}, \mathrm{Nb}$, Mo and $\mathrm{Ta}$ have a Beta-isomorphous effects. By exceeding the equilibrium concentration (5 wt. \% Al), secondary compounds such as Ti3 Al come to separate from the solid solution. Alpha -2 phase exerts a strong reinforcing effect, manifested by increase of hardness, which diminishes the plasticity of the alloy and reducing the cold-working possibilities. Therefore, it is recommended to limit the aluminium content in titanium alloys to a maximum of $8 \mathrm{wt} . \% \mathrm{Al}$ [8]. For reducing the Young's modulus value of titanium alloy (usually of 103-120 GPa), elements which stabilize Beta phase are required, to reaching the level of cortical bones for this parameter (10-30 GPa) $[1,5]$. Also, another method for improve the mechanical characteristics values is grains refinement, which can be obtained by boron addition [9].

For developing TiAl-base alloys for structural applications, vanadium addition and some heat treatments was made to obtaining good mechanical characteristics [10]. Aluminium is alpha phase stabilizer and increases the temperature of Beta transformation in Ti-Al system [11]. In biocompatible alloys aluminium is not a desired element, intoxications with metallic aluminium being recognised in occupational medicine at patients that are subjected to renal dialysis [12-16].

The maximum solubility of $\mathrm{Fe}$ in Alpha-Ti is about 1 at $\% \mathrm{Fe}$ for a concentration of 44 at $\% \mathrm{Al}$ [11]. Iron toxicity is very low and the compounds resulting during oxidation process do not accumulate in tissues, being immediately metabolised [14-16]. Iron and manganese are $\beta$-eutectoid stabilizers elements in Ti-alloys.

Manganese presence in titanium alloys has similar effect to those of aluminium [13]. In titanium alloys, Mn presence allow to increase significantly the hardness from $83.3 \mathrm{GPa}$ (Ti2Mn) to $122 \mathrm{GPa}$ (Ti12Mn) but decrease the plasticity, from $21.3 \%$ to $11.7 \%[14,15]$. Like iron, manganese is an essential element and plays a primary role in the activation of multiple enzyme systems [16-18], having special role as a co-factor in the formation of bone cartilage and bone collagen, as well as in bone mineralization [19, 20]. Among the $\mathrm{Ti}$ alloys, Beta-Ti are most used when the optimum combination of characteristics are required (in respect of processing ability and physical-chemical- and mechanical properties) comparatively with any other class of alloys [21, 22]. Concentrations below 8 wt. \% Mn in titanium reveal negligible effects on the metabolic activity and the cell proliferation of human osteoblasts [23, 24]. Other elements like $\mathrm{Zr}$, Ta, Mo and $\mathrm{W}$ allow increasing the microhardness and compression strength of titanium-base alloys [25-28]. Iron and manganese additions in titanium alloys are beneficial for improving the mechanical characteristics without affecting the biocompatibility. From metallurgical point of view, these elements contribute to enhance the nucleation rate and slow the growth rate of grains, influencing the liquid/solid interfacial characteristics [25, 29].

The paper analysed the effects of chemical elements like Al, Fe and Mn on the microstructure and microhardness of titanium alloys for medical applications. The concentration of the main alloying elements has been modified to analyse the changes produced on microstructure and microhardness of Ti-base alloys. Compared to other studies, the paper presents the cumulative effects of $\mathrm{Fe}$ and $\mathrm{Mn}$ elements, both considered biocompatible, with the purpose of developing new alloys, without aluminium and vanadium.

\section{Materials and methods}

Due to the specific properties of titanium and its alloys, such as the high melting temperature, as well as the sudden increase of the chemical activity as the temperature rises, they are obtained in electric arc and induction furnaces, only in vacuum or under inert gas protection [25].

The experimental alloys studied in the paper were produced by melting in VAR MRF ABJ 900 equipment from ERAMET Laboratory of Materials Science and Engineering Faculty, University Politehnica of Bucharest, using high purity metallic materials. In VAR equipment the raw materials are melting quickly using an electric arc formed between a W-Th electrode and the metallic batch, under argon inert atmosphere. Before the melting operations, a vacuum of $4.5 \times 10^{-3}$ mbar was performed, followed by the purging using inert gas (Ar 5.2), the cycle being repeated four times to 
realize working atmosphere purification. In order to refine and homogenize the metallic material, the alloy is three times re-melted, on each part, and then is fast cooled on copper plate of the equipment.

The alloys composition was conducted by changing the content of chemical elements like $\mathrm{Fe}, \mathrm{Mn}$ and Al. The chemical composition of the experimental alloys was determined both by Spark Optical Emission Spectrometer - SPECTROMAXx M using Ti-01-M program and by EDAX analyse (Table 1).

Table 1. Chemical composition of experimental Ti-base alloys, at $\%$

\begin{tabular}{cccccc}
\hline Alloy & Mn & Fe & Al & V & Ti \\
\hline Ti11AlVFe & 0 & 2.59 & 11.35 & 3.05 & \multirow{2}{*}{ Balance } \\
\cline { 1 - 5 } Ti18AlFeV & 0 & 7.81 & 18.58 & 5.11 & \\
\hline TiMnAlFeV & 6.59 & 1.19 & 2.50 & 2.30 & \\
\hline
\end{tabular}

After cooling, the metallic samples were examined and sectioned to preparing for metallographic analyze and microhardness test. The Ti-base alloys samples were cut for metallographic analysis using a precision cutting machine IsoMet 4000 and metallographic discs under cooling fluid (in Lamet Laboratory, from UPB). The selected samples has been embedded in resin and polished using metallographic paper with different grain sizes (600 to 2500 grit paper), followed by polishing with abrasive powder (grain size between 0.6 to $0.1 \mu \mathrm{m}$ ).

To highlight the microstructure aspect, metallographic etching reagent was used with the following composition: $10 \% \mathrm{HF}+30 \% \mathrm{HNO}_{3}+50 \mathrm{ml}$ deionized $\mathrm{H}_{2} \mathrm{O}$. The samples were examined by optical microscopy (Olympus GX51 optical microscope) and by scanning electron microscopy SEM (Inspect S, FEI equipped with EDAX Z2e analyser).

\section{Results and discussions}

\subsection{Microstructure}

Ti-Al alloys are used mainly because of their high thrust-to-weight ratio of high -performance aircraft engines. Aluminium is one of the few alloying elements that lead to an increase in the allotropic transformation temperature of the titanium. As can be seen in the equilibrium diagram (Figure 1), aluminium forms a wide range of solid solutions with titanium, its solubility being 25 at $\%$ $\mathrm{Al}$ at $1400{ }^{\circ} \mathrm{C}$ and 6 at\% $\mathrm{Al}$ at ambient temperature. Aluminium is considered to be the main alloying element of titanium, being present in most alloys of this metal. Its effect in titanium is considered similar to that of carbon in iron alloys. If aluminium concentration in titanium-base alloy is $10 \mathrm{wt} \%$ or more, according $\mathrm{Ti}-\mathrm{Al}$ phase diagram $\mathrm{Ti}_{3} \mathrm{Al}$ intermetallic second phase can forms [27].

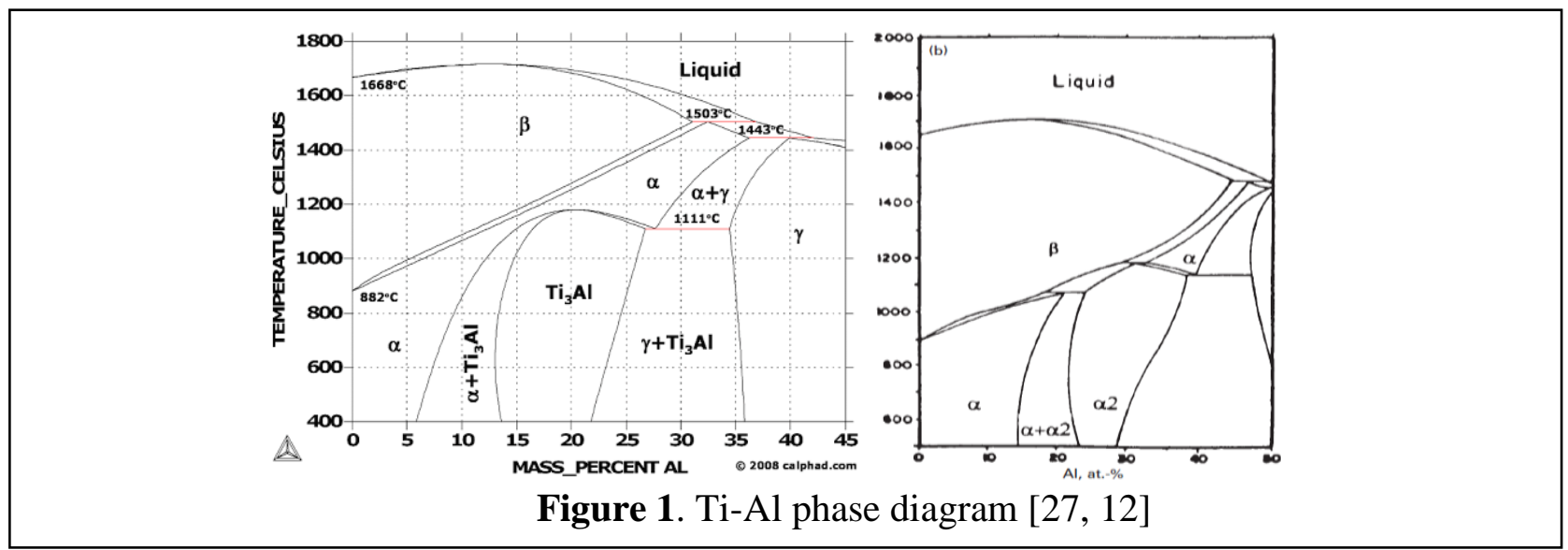

The mechanical properties of two-phase $(\alpha+\beta)$ titanium alloys depend on the phases morphology. The proportion of lamellar structure is important due to their high resistance to fatigue crack and good 
fracture toughness. During technological processing of two-phase Ti-alloys, the $\beta$-grain size of lamellar phase must be kept as fine as possible.

For increase the proportion of Ti- $\beta$ phase, the experimental alloys were alloying with $\beta$-eutectoid stabilizers, like Fe and Mn. Depending on the iron concentration in Ti-Fe diagram, some intermetallic compounds can be formed (Figure 2).

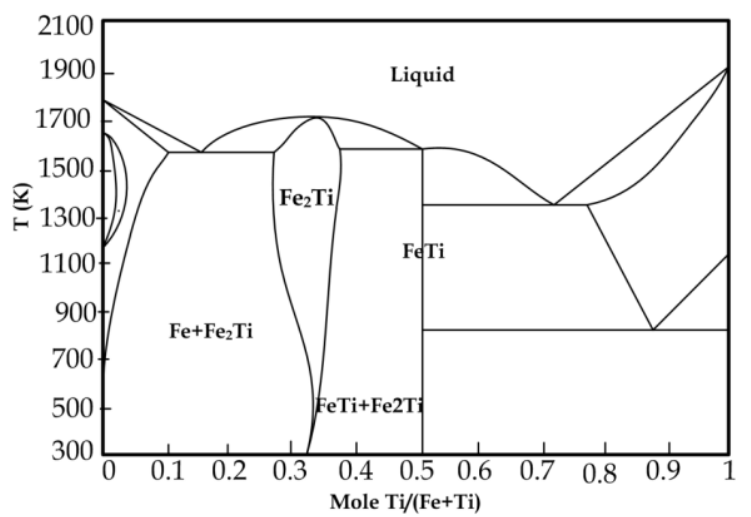

Figure 2. Ti-Fe phase diagram [31]

By restricting the grain growth tendency, iron help in grain refinement of the microstructure in titanium alloy. Analysing Ti-Fe system the following compounds can be formed: $\mathrm{TiFe}_{2}$ (congruent, melting point at 1700 $\mathrm{K}), \mathrm{TiFe}$ (incongruent, melting point at $1650 \mathrm{~K}$ ), $\mathrm{Ti}_{2} \mathrm{Fe}$ (incongruent, melting point at $1358 \mathrm{~K}$ ). The most stable compound is $\mathrm{TiFe}_{2}$ [17, 19 and 28]. The increase of chemical elements concentration ( $\mathrm{Al}, \mathrm{V}$ and $\left.\mathrm{Fe}\right)$ in the $\mathrm{Ti}$ base alloy allows to changing the $\beta$-phase proportion, although alpha phase is still present. In the case of experimental alloys Ti11AlV2Fe the microstructure is bi-phasic $(\alpha+\beta)$, even V and Fe concentrations are low (Figure 3), the Ti- $\alpha$ phase being preponderant.

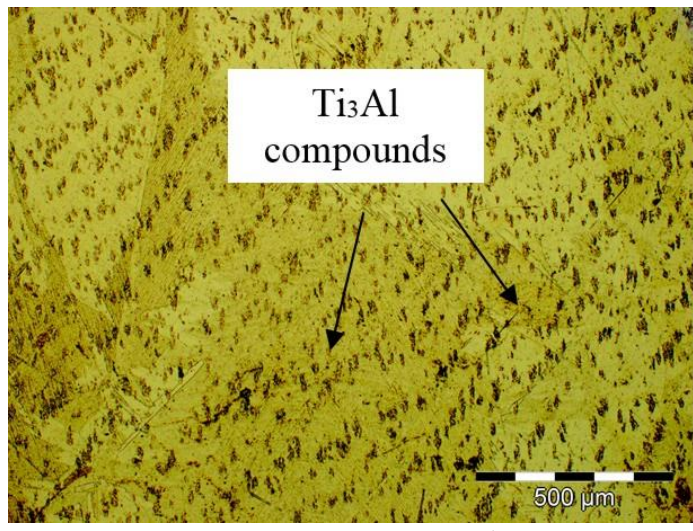

a)

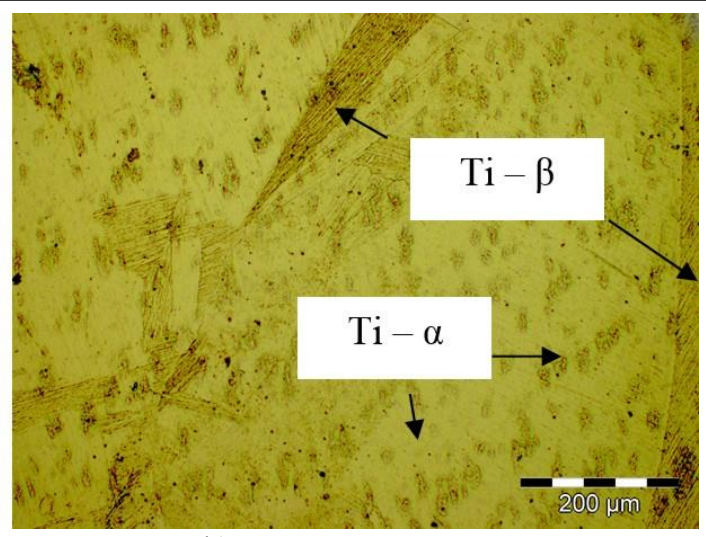

b)

Figure 3. Optical microstructure of experimental Ti11 AlV2Fe alloy: a) Overview microstructure; b) Detail on Ti- $\beta$ and Ti- $\alpha$ phases

Increasing of content over $7 \mathrm{wt}$. \% Fe in Ti-Al metallic matrix allows to a spheroidization tendency of $\mathrm{TiFe}_{2}$ compounds (Figure 4). 


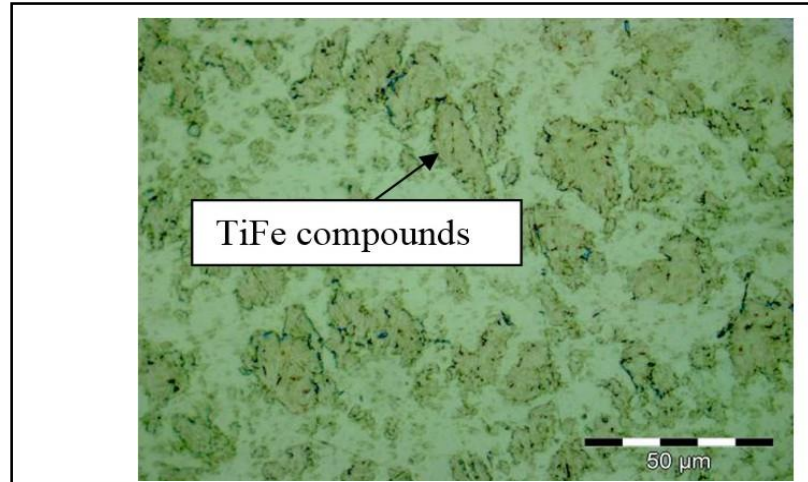

a)

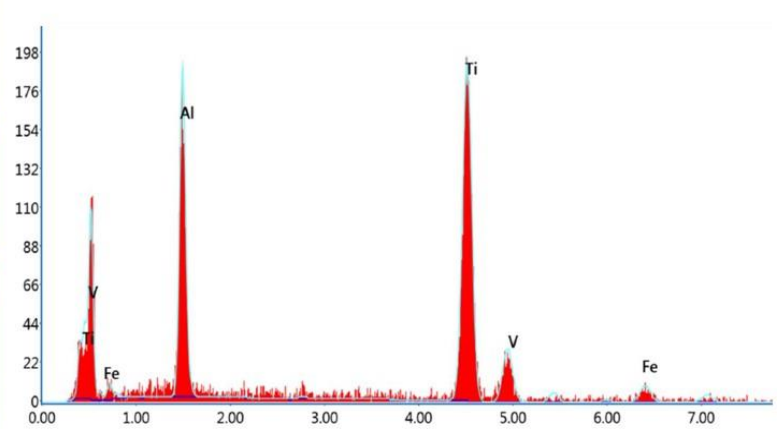

b)

Figure 4. Optical microstructure of Ti18Al5V7Fe alloy (a) and X-Ray spectrum of elements (b)

Some alloys like Ti2Mn, Ti5Mn, and Ti8Mn have good mechanical properties and acceptable cytocompatibility, being used as bone substitutes or a good dental implants alternative [24].

The maximum solubility of $\mathrm{Mn}$ in $\beta$-Ti is about 30 at $\%$ at $1174{ }^{\circ} \mathrm{C}$ while the maximum solubility of $\mathrm{Mn}$ in $\alpha$-Ti is 0.4 at\% below $882^{\circ} \mathrm{C}$ [30]. By alloying titanium with $\mathrm{Mn}$ (6.59\%wt Mn), quasi-rounded intermetallic compounds have separate from the metallic matrix (Figure 5a) and $\beta$ phase stabilization with uniform equiaxed grains and lamellar aspect is achieved (Figure 5b).

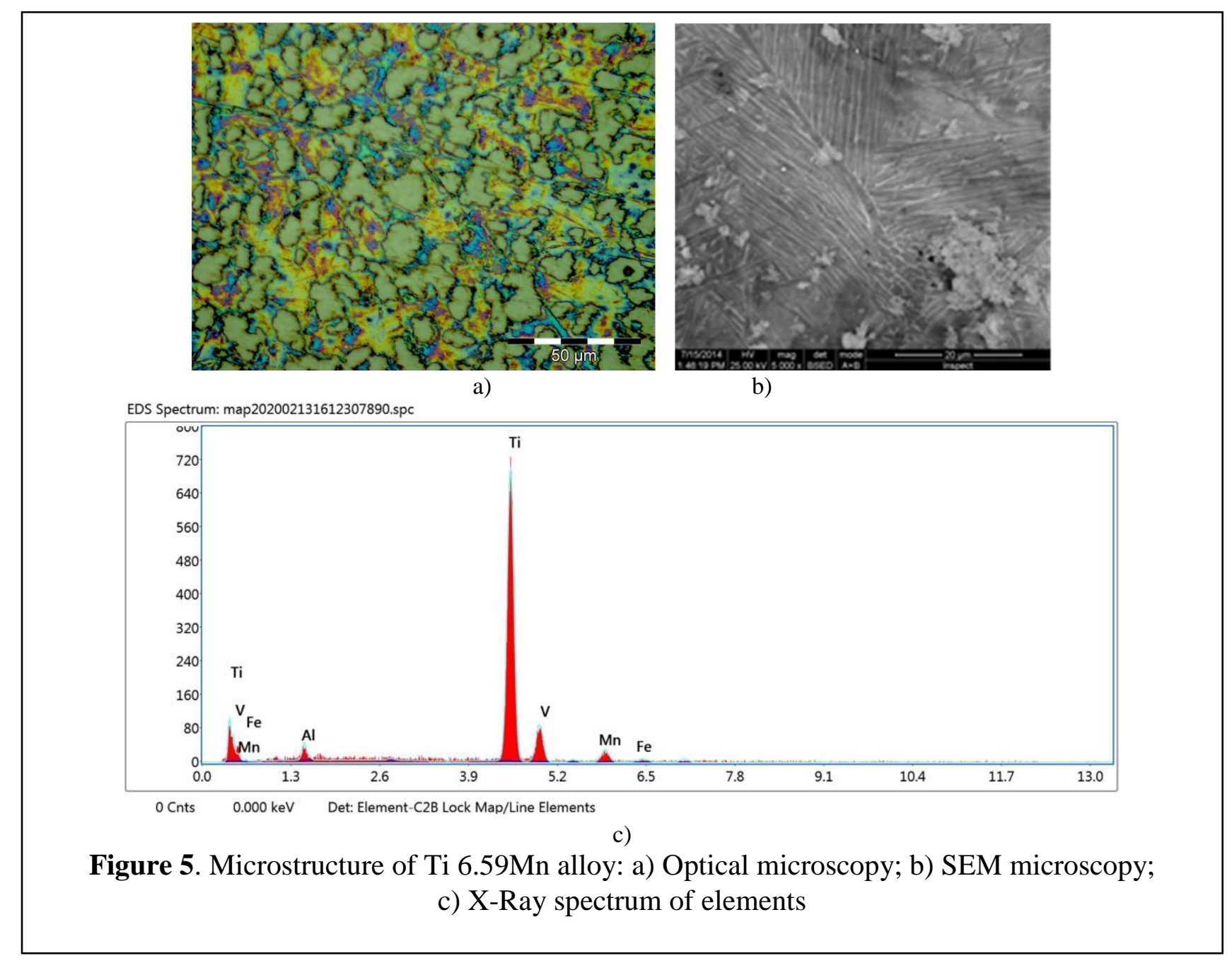




\subsection{Microhardness}

Microhardness measurements have been performed using Shimadzu HMV 2T tester, using applied loads of $980.07 \mathrm{mN}$ and testing time of 10 seconds. The average values of microhardness, measured in 10 different points of the alloys analysed in this paper, are shown in Figure 6. In this figure are shown also some data regarding other T-base alloys containing $\mathrm{Mn}$ and $\mathrm{Fe}$, obtained and tested by the authors of this paper.

As can be seen from the microhardness evolution, the general trend is the increase of hardness by alloying with $\mathrm{Fe}$ and $\mathrm{Mn}$, explained by double effect of solid solution strengthening mechanism and hard compounds formation. The maximum hardening effect is obtained for Ti18Al7.8Fe5V alloy (almost double comparatively with commercial Ti8A14V alloy).

$\mathrm{Fe}$ acts like the strongest hardening element in Ti-base alloys. For concentration exceeding 5 at $\% \mathrm{Fe}$, the microhardness was with $50 \%$ greater comparatively with commercial Ti8Al4V alloy.

The hardening effect provided by $\mathrm{Mn}$ in Ti-Base alloy is superior to those obtained by alloying with $8 \mathrm{wt}$. $\% \mathrm{Al}$ and $4 \mathrm{wt}$. $\% \mathrm{~V}$. The main advantage of using Mn as alloying element for biomedical applications is his biocompatible effect.

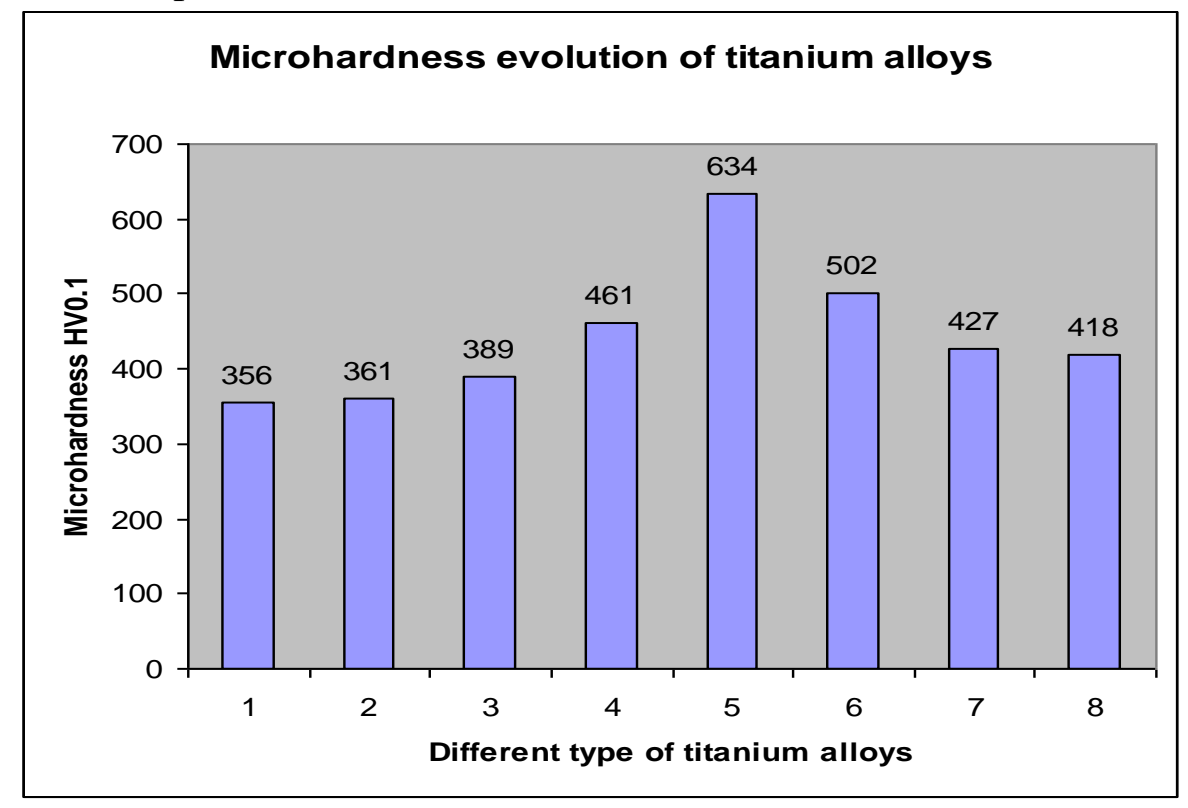

Figure 6. The microhardness average values for different type of titanium alloys. 1 - Ti8Al4V alloy; 2 - Ti8Al4V remelted;

3 - Ti8AlV; 4 - Ti11Al3V2.59Fe; 5 - Ti18Al7.8Fe5V; 6 - Ti5Fe; 7 - Ti 6.59Mn; 8 - Ti3Mn

\section{Conclusions}

Alloying elements have different effects on the microstructure and the microhardness of Ti-base alloys. For the content below 8 wt. \% Al, alpha phases has lamellar aspect and above this value, Ti3 $\mathrm{Al}$ compounds are separated in the form of scattered islands of irregular shape.

Iron allows to grain refinement and influence spheroidization tendency of Ti-Fe compounds, contributing to matrix reinforcement.

By increasing the manganese concentration in the Ti-base alloy increases the proportion of intermetallic compounds that can separate from the metallic matrix, having fine and lamellar appearance. A substantial increases of the microhardness in analyzed titanium alloys promote Fe, $\mathrm{V}$ and Al. These elements can act simultaneously for increasing the hardness, such is the case of Ti18Al7.8Fe5V alloy, having $634 \mathrm{HV} 0.1$. An individual hardening effect has been obtained for Ti5Fe alloy, having hardness of $502 \mathrm{HV} 0.1$. Effect of Mn on the increasing of hardness was less important, yielding a slight increase of microhardness from 418HV0.1 for Ti3Mn to 427HV0.1 for Ti6.59Mn. 
Acknowledgments: This work was supported by a grant of the Romanian Ministry of Research and Innovation, CCCDI - UEFISCDI, project number PN-III-P1-1.2-PCCDI-2017-0239/60 PCCDI 2018, "Obtaining and Expertise of New Biocompatible Materials for Medical Applications MedicalMetMat", within PNCDI III.

\section{References}

1. NIINOMI, M., Recent research and development in titanium alloys for biomedical applications and healthcare goods, Science and Technology of Advanced Materials 4, 2003, 445-454.

2. OLDANI, C., DOMINGUEZ, A. Titanium as a Biomaterial for Implants, Recent Advanced in Arthroplasty, 2012, 149-162.

3. BALTATU, M.S., VIZUREANU, P., GEANTA, V., TUGUI, C.A. and VOICULESCU, I., Mechanical tests for Ti-based alloys as a new medical materials, IOP Conf. Series: Materials Science and Engineering, 572, 2019, doi:10.1088/1757-899X/572/1/012029.

4. GRANDIN, H.M., BERNER, S., DARD, M. A Review of Titanium Zirconium (TiZr) Alloys for Use in Endosseous Dental Implant, Materials, 5, 2012, 1348-1360.

5. ELIAS, C.N., LIMA, J.H.C., VALIEV, R., MEYERS, M.A. Biomedical Applications of Titanium and its alloys, Biological Materials Science, 2008, p. 47-49.

6.NIINOMI, M. Biologically and Mechanically Biocompatible Titanium Alloys, Materials Transactions, 49, (10), 2008, 2170-2178.

7. JEONG, H.W., KIM, S.E., HYUN, Y.T., LEE, Y.T., PARK, J.K. Microstructures and Elastic Moduli of Binary Titanium Alloys Containing Biocompatible Alloying Elements, Materials Science Forum, 475-479, 2005, 2291-2294.

8. BREME, H.J., HELSEN, J.A. Metals as Biomaterials-Selection of Materials, Biomaterials Science and Engineering Series, Wiley, 1998, 20-21.

9. MALEK, J., HNILICA, F., VESELY, J. Beta Titanium Alloy Ti35Nb6Ta with Boron Addition, Metal, Czech Republic, 2012, 6.

10.VOICULESCU, I., DONTU, O., GEANTA, V., GANATSIOS, S. Effect of the Laser Beam Superficial Heat Treatment on the Gas Tungsten Arc Ti-6Al-V Welded Metal Microstructure, Conference on Industrial Laser Applications, 7007, 2007, 703-706.

11.DE FARIAS AZEVEDO, C.R., FLOWER, H.M., Microstructure and phase relationships in Ti-AlSi System, Materials Science and Technology, 15, 1999, 869-877.

12. HAO, Y.L., XU, D.S., CUI, Y.Y., YANG, R., LI, D., Acta Mater. 47, 1999, 1129;

13.SAUNDERS, N. Phase Equilibria in Multi-Component $\gamma$-TiAl Based Alloys, "Gamma Titanium Aluminides", 1999, 183.

14.ZHANG, F., BURKEL, E. Novel Titanium Manganese Alloys and Their Macro-porous Foams for Biomedical Applications Prepared by Field Assisted Sintering, Biomedical Engineering, Trends in Materials Science, 9, 2011, 203-224, www.intechopen.com.

15.BREME, H.J., BIEHL, V., HELSEN, J.A. Metals and implants, Biomaterials Science and Engineering Series, Wiley, 1998, 54-55.

16.HILDEBRAND, H.F., HORNEZ, J.C. Biological response and biocompatibility, Biomaterials Science and Engineering Series, Wiley, 1998, 268-270.

17.SHANK, F., Structure of binary alloys, M: Metallurgy, 1973, 759.

18.HANSEN, M., ANDERKO, K. Structure of binary alloys, Vol. 1, 1962, 607.

19.HANSEN, M., ANDERKO, K., Structure of binary alloys, Vol. 2, 1962, 1487.

20.BALTATU, M.S., TUGUI, C.A., PERJU, M.C, BENCHEA, M., SPATARU, M.C., SANDU, A.V., VIZUREANU, P., Biocompatible Titanium Alloys used in Medical Applications, Rev.Chim. 70 (4) 2019, 1302-1306.

21.POPA, M.V., VASILESCU, E., DROB, P., COJOCARU, D., VASILESCU, C. Effect of pH on the Behaviour of Some Titanium Alloys with Biphasic Structure, Rev.Chim., 60 (1) 2009, 29-33. 
22.TAMIRISAKANDALA, S., BHAT, R.B., TILEY, J.S., MIRACLE, D.B. Grain refinement of cast titanium alloys via trace boron addition, Scripta Materialia, 53, 2005, 1421-1426.

23.BERMINGHAM, M.J., McDONALD, S.D., DARGUSCH, M.S., ST- JOHN, D.H. Microstructure of Cast Titanium Alloys, Materials Forum, 31, 2007, 84 - 89.

24.ZHANG, F., WEIDMANN, A., NEBE, J.B., BECK, U., BURKEL, E., Preparation, microstructures, mechanical properties and cytocompatibility of TiMn alloys for biomedical applications, J. Biomed Mater, Res B, App. Biomater., 94 (2) 2010, 406-413.

25.BUZATU, M., GEANTA, V., STEFANOIU, R., BUTU, M., PETRESCU, I., BUZATU, M., ANTONIAC, I.V., IACOB, G., NICULESCU, F., GHICA, S.I., MOLDOVAN H. Investigations into Ti-15Mo-W Alloys Developed for Medical Applications, Materials 12 (147) 2019, doi: 10.3390/ma12010147.

26.TUDORAN, S., VOICULESCU, I., GEANTA, V., VIZUREANU, P., MIRZA ROSCA, J.C., PATRASCU, I., GALBINASU, B.M., CIOCOIU, R., Effects of the chemical composition on the microstructural characteristics of Ti-Nb-Ta-Zr alloys, ICIR Conference, 572 (1) 2019 doi:10.1088/1757-899X/572/1/012022.

27.***http://www.calphad.com/titanium-aluminum.html.

28.LOUZGUINE-LUZGIN, D. V. High-Strength Ti-Based Alloys Containing Fe as One of the Main Alloying Elements, Materials Transactions, 59 (10) 2018, 1537-1544.

29.RAGHAVAN, V., Phase diagrams of ternary iron alloys, ASM International, 1987.

30. KHAN, A. U., BROZ, P., PREMOVIC, M., PAVLU, J., VRESTAL, J., YAN, X., MACCIO, D., SACCONE, A., GIESTER, G., ROGI, P., The Ti-Mn system revisited: experimental investigation and thermodynamic modelling, Chem. Phys., 18, 2016, 23326-23339, https://doi.org/10.1039/C6CP04542A. 31.www.intechopen.com/books/metal-ceramic-and-polymeric-composites-for-various-uses/in-situdeposition-of-metal-matrix-composite-in-fe-ti-c-system-using-laser-cladding-process.

$\overline{\text { Manuscript received: } 27.02 .2020}$ 